\title{
Developing a Faculty Learning Community for Non-Tenure Track Professors
}

\author{
Nathan Bond ${ }^{1}$ \\ ${ }^{1}$ Professor, Department of Curriculum \& Instruction, Texas State University, USA \\ Correspondence: Nathan Bond, Professor, Department of Curriculum \& Instruction, Texas State University, USA
}

Received: August 5, 2015

Accepted: August 20, 2015

Online Published: September 4, 2015

doi:10.5430/ijhe.v4n4p1

URL: http://dx.doi.org/10.5430/ijhe.v4n4p1

\begin{abstract}
Non-tenure track faculty vary greatly in terms of their ranks, teaching abilities, workloads, and motivational levels and have unique professional development needs. In response, universities are differentiating professional development for these professors. This case study examined an emerging research university's efforts to provide a faculty learning community (FLC) for its non-tenure track professors. Data were collected during an academic year from interviews with the participants, evaluations completed by the participants after the meetings, and the facilitators' curricular materials. The participants learned useful instructional strategies and felt more connected to their colleagues, more supported by the university, and more confident in their teaching. The findings suggest that FLCs are a viable method of professional development for non-tenure track faculty.
\end{abstract}

Keywords: Faculty learning community, Non-tenure track faculty, Professional development

\section{Introduction}

\subsection{Introduction}

Non-tenure track faculty have increased dramatically in numbers during the last two decades (U.S. Department of Education, 2009). According to some reports, they now account for $79 \%$ of all faculty at four-year institutions (Barnshaw \& Dunietz, 2015). Future projections indicate that universities will continue hiring more non-tenure track faculty due to the changing social, economic, and political factors affecting higher education (Kezar, 2012; Kezar \& Sam, 2011; Schuster \& Finkelstein, 2006; Wong, 2013). Hiring this type of professor allows universities to reduce expenses related to wages, health care, and professional development while infusing the institution with unique talents and perspectives (Maisto \& Street, 2011). As Thedwall (2008) stated, "Clearly non-tenure track faculty are here to stay, and stay in large numbers" (p. 18).

\subsection{Introduction of the Problem}

Non-tenure track faculty pose unique challenges to universities. These professors vary in terms of their ranks, teaching abilities, workloads, and motivational levels. The group's diversity is reflected by their various titles: adjunct faculty; lecturers; senior lecturers; and clinical, research, and visiting professors (Garii \& Petersen, 2006; Parrott et al., 2007). One problem is that some non-tenure track faculty, compared to their tenure-eligible colleagues, struggle to provide the same quality of instruction. Consequently, their students often learn less and are retained at lower rates (American Association of University Professors, 2011). Another problem is that many non-tenure track faculty work part time, teaching a course or two at an institution. Thus, they may not be integrated fully into the university's culture (Garii \& Petersen, 2006). Some are highly motivated professors pursuing tenure-track positions; others, less driven, teach for the sheer enjoyment of teaching and change positions frequently when new and more interesting opportunities arise (Cross \& Goldenberg, 2009; Gappa \& Leslie, 1993). In other words, their loyalty to the university varies.

Yet another problem is that because non-tenure track faculty are diverse, they have the unique professional development needs (Cressman, 2011). In response, universities are offering specialized support through new employee orientations (Gadberry \& Burnstad, 2005) and ongoing professional development and mentoring (Baron-Nixon, 2007). Although these efforts are effective, universities are searching for additional ways to retain the professors and help them to deliver high-quality instruction. College students expect all of their professors, 
regardless of rank and employment status, to teach in engaging ways that spark learning (Dolan, Hall, Karlsson, \& Martinak, 2013).

\subsection{Purpose of the Study}

The purpose of this case study was to examine one university's efforts to meet the professional development needs of its non-tenure track faculty through the use of a cohort-based faculty learning community (FLC). Cox (2004), a leading scholar in the field, states that a cohort-based FLC forms when five or more cross-disciplinary professors of the same rank or type engage over a period of time in an active and collaborative program that strives to enhance teaching, increase student learning, and build a sense of community. Since the late 1970s, FLCs have worked well with tenure-track professors (Cox, 2013; Hadar \& Brody, 2010; Smith et al., 2008); however, FLCs have been used limitedly with non-tenure track professors (Brydges et al, 2012; Lambert \& Cox, 2007). Cohort-based FLCs appear to be a promising way to address "the teaching, learning, and developmental needs of an important group of faculty or staff that has been particularly affected by isolation, fragmentation, stress, neglect, or chilly climate in the academy" (Cox, 2004, p. 8).

\section{Review of the Literature}

\subsection{Professional Development for Non-Tenure Track Faculty}

Non-tenure track faculty engage in formal and informal professional development. Formal professional development generally includes three components: orientations, ongoing workshops, and inclusiveness. Orientations allow universities to explain their work culture and practices to new faculty (Lyons, 2007). In a survey of the adjuncts in the Brigham Young University system, Hoyt (2012) found that most were generally satisfied with the professional development they received, but they wanted more of it. In response, the university provided orientations, mentors, and trainings that focused on departmental policies and teaching methods. In spite of these efforts, only half of the adjuncts participated. The researcher recommended that universities offer professional development at appropriate times and that adjuncts capitalize on these experiences. He stated that at a minimum, "each new faculty member should be required to complete an orientation, provided with a handbook or online resources, assigned to a faculty mentor, given ongoing training, and thanked for his or her contributions" (Hoyt, 2012, p. 140).

Second, ongoing workshops strengthen professors' skills in teaching, assessment, and classroom management (Lyons, 2007). After examining a group of administrators who hosted a successful conference for adjuncts at a university in Illinois, Johnson and Stevens (2008) concluded that faculty development programs should be multi-faceted to account for the diversity among professors. Some adjuncts prefer learning information in person; others, online. Administrators should also consider the methods for advertising workshops, the expectations for attendance, and the reimbursements for travel and lost time from other jobs (Gillespie \& Roberton, 2010).

To determine the specific topics of the workshops, Dolan, Hall, Karlsson, and Martinak (2013) surveyed more than 1,600 adjuncts in Maryland. Viewed most favorably by the adjuncts in decreasing rank order were instructional methods, student motivation, assessment techniques, technology integration into instruction, diverse student populations and learning styles, and strategies for fostering critical thinking skills. The adjuncts preferred workshops during the weekdays over those in the evenings and on weekends, and they preferred face-to-face sessions over online formats. As to frequency and duration of the workshops, half responded that one offering of two to three hours each semester was sufficient.

Third, a sense of belonging or inclusiveness is an important component of professional development for non-tenure track professors. Often they feel undervalued, unappreciated, and excluded by their institutions (Gillespie, Robertson, \& Associates, 2010). Because she had experienced these feelings earlier in her career as an adjunct professor, Schreyer (2012) developed a series of workshops for her part-time colleagues in compositional studies at her university. Rather than hiring outside presenters, she asked the adjunct faculty to conduct the workshops and showcase their unique teaching methods. At the conclusion of the series, the professors felt empowered because "their professional expertise had been respected" (Schreyer, 2012, p. 94). In addition, they felt more valued by administrators and colleagues, more involved in the department, and more committed to the success of the degree program.

Another aspect of inclusiveness is that non-tenure track faculty learn informally through day-to-day interactions with colleagues (Cilliers \& Herman, 2010; Webster-Wright, 2009). In one study, five lecturers in Ireland maintained notebooks of significant instances of learning that they noticed while teaching (Breen, McCluskey, Meehan, O'Donovan, \& O'Shea, 2014). After reflecting individually on the instances, the lecturers shared their insights with one another. The opportunity to share enabled them to reflect more deeply on their teaching and improve their 
instruction. In a similar study from Australia, lecturers, equivalent to instructors in the United States, videotaped themselves teaching and then reflected as a group on the videos (Barton, Oates, Paterson, \& Thomas, 2015). The group's dialogue contributed to their improved teaching.

In summary, the research recommends that universities provide non-tenure track faculty with opportunities and support for professional development (Cross \& Goldenberg, 2009; Hoeller, 2014). Some universities are doing a satisfactory job differentiating professional development for these professors while others are not (Dolan et al., 2013). Although the studies present positive results, scholars are calling for more research to examine the impact of professional development on actual teaching practices (Stes, Min-Leliveld, Gijbels, \& Van Petegem, 2010). The ultimate goal is to help professors improve teaching effectiveness and increase student learning (Cilliers \& Herman, 2010).

\subsection{Cohort-based Faculty Learning Communities}

The scholarly literature focuses on the implementation of cohort-based FLCs and the benefits that professors reap from participating in them. In his well-established FLC model, Cox (2004) advises university administrators to include the following components: purpose, curriculum, administration, connections and affiliated participants, scholarly process, assessment, and enablers and rewards. When faculty meet in a FLC, they typically complete short readings, planned activities, and discussions of the information and its connection to their work (Alejano-Steele et al., 2011). Open discussions about teaching occur only when professors feel emotionally safe and supported by others (Furco \& Moely, 2012). As faculty grow more comfortable with one another over time, the FLC evolves and passes through stages of development, moving first from a period when people are unsure of their roles and purpose to a time when members productively engage in the task at hand (Hubball \& Albon, 2007).

Faculty benefit from participation in FLCs. A review of the literature uncovered five empirical studies that investigated cohort-based FLCs comprised of professors at various stages of their careers, with two of them specifically involving non-tenure track faculty. Lambert and Cox, (2007) describe a cohort-based FLC for adjunct faculty at Miami University in Oxford, Ohio. Rather than implementing a full-fledged experience for the part-time professors, these researchers developed what they called "FLC lite," which lasted one semester and omitted the production of the scholarly project (p. 220). This modified version still involved professors from various departments, a focus on teaching, and incentives for attendance. Although the meetings were successful, few people attended. As Lambert and Cox (2007) explained,

Their reasons included lack of time; costs of traveling to meetings; lack of departmental encouragement for participation; a sense that the program seemed to be aimed more at new part-time faculty while ignoring the skills, experience, and diversity of many (or most) part-time faculty; and that most of the sessions were on the Oxford campus, while most of the part-timers were on the regional campuses (p. 222).

The researchers adjusted their approach and implemented the FLC lite the second year with greater success.

Brydges et al. (2012) examined a group of lecturers at the University of California, San Diego, who formed a cohort-based FLC to learn instructional strategies for teaching classes with large enrollments. Over the course of an academic year the professors learned technological tools to enhance student learning and strategies for incorporating teaching assistants in the instruction of the courses. With their university's emphasis on research, the lecturers were able to discuss discipline-based research and develop scholarly projects in their fields.

Cox (2013) summarized a series of studies that he conducted over a 30-year period that focused initially on cohort-based FLCs for early-career academics. In the 1980s, the FLCs for these beginning professors were successful and received national recognition for generating positive results on undergraduate teaching and learning. During the 1990s and 2000s, the FLCs were expanded to include professors at later stages of their careers, and the results were again positive. When other universities implemented FLCs, they also experienced success. Cox (2003) discovered that professors who participated in FLCs were tenured at significantly higher rates than were non-participants. Furthermore, he found that FLCs increased professors' interest in the teaching process, their comfort as members of the university community, and their understanding of the scholarship of teaching and learning. Cox (2013) concluded that if a university wants to become a learning organization that is continually gaining new knowledge and improving its outcomes (Senge, 1990), then it must connect faculty, especially the early-career academics, to its mission and give them opportunities to learn in groups such as cohort-based FLCs.

In a similar study, Hershberger et al. (2009) examined cohort-based FLCs designed to help tenure-track professors at different universities to balance their teaching and research and to view teaching as a form of scholarship. The researchers determined that the tenure-track professors taught more effectively, managed their time better, increased 
their scholarly productivity, and enjoyed stronger collegial relationships. The support and sense of community that developed played an important role in producing these outcomes.

Finally, Blaisdell and Cox (2004) synthesized the findings from 11 years of hosting cohort-based FLCs for midcareer and senior faculty members at Miami University. These experienced professors participated "because they wanted to take their work in new directions and because they longed for sharing with new discussion partners" (p. 138). At the end of the FLC, they felt rejuvenated and motivated to continue their productive academic lives. They enjoyed getting to know professors from other subject areas and learning how these colleagues presented information to students.

In summary, cohort-based FLCs generally follow Cox's well-established model for implementation. Cultivating a trusting and respectful climate in the FLC is critical to its success. When faculty feel emotionally safe, they are willing to talk about their teaching, and, consequently, they reap the benefits of the professional development approach.

\section{Method}

This qualitative case study examined the effects of a cohort-based FLC for non-tenure track faculty at a large (>35,000 students) university located in the southwestern United States. Designated by the Carnegie Foundation as an Emerging Research Institution, the university employs 919 non-tenure track faculty. The Office of Academic Development and Assessment, the sponsor of the FLC in this study, is charged by the university to provide professional development that will help professors to improve their teaching and research.

\subsection{Implementation of the FLC}

To guide the implementation of this method of professional development that was new to his institution, the researcher followed Fullan's (2007) three-step process for fostering change in educational systems: initiation, implementation, and institutionalization. Only the first two steps were completed because it takes several years for a university to embed or institutionalize the new initiative in its system.

Fullan (2007) states that during the initiation phase, the leader connects the initiative to an apparent need based on the school's values and norms. The researcher, who also served as the assistant director of the Office of Academic Development and Assessment, had received requests from non-tenure track faculty who wanted professional development that would meet their unique needs. In response to these requests, he explored the published literature on professional development in higher education and discovered FLCs. He realized that FLCs are very similar to professional learning communities (PLCs), a type of professional development for teachers at the K-12 level. He had extensive previous experience with PLCs.

During Fullan's (2007) second step, the implementation phase, the leader works with the other decision makers to establish the structures and launch the new initiative. Since FLCs appeared to be a suitable method for providing professional development to the non-tenure track faculty, the researcher explored the nine components of Cox's FLCs (2004) and employed many of them in his plan, although not all components were implemented exactly as Cox advises. As Mallory, Fisher, Witham, and Gultice (2014) explain:

A formal FLC is not necessarily required to achieve [positive] results. Faculty who face a common problem or challenge, particularly faculty within related disciplines, may benefit from a structured, yet less formal approach that allows for the sharing of ideas, peer-review, and development of new course materials that directly impact student learning (p. 193).

The following sections provide an overview of the nine components and the ways they were implemented.

\subsubsection{Affiliated Participants/Campus Support}

The FLC was officially sponsored by the Office of Academic Development and Assessment. No other administrative office or group on campus offered support to the FLC.

\subsubsection{Mission and Purpose}

The researcher completed the Cox's (2009) Faculty Learning Community Goals Inventory and identified the top three goals for the FLC, which were "fostering colleagueship and learning from others," "developing increased individual teaching skill and ability," and "learning more about a specific pedagogical tool or strategy." Since FLCs had never been offered before at this university, the researcher wanted to keep the first one straightforward and uncomplicated. 


\subsubsection{Curriculum}

The FLC met three times during the fall semester and three times during the spring semester. For the fall semester the researcher selected topics that he considered foundational to teaching at the university level. The topics were "delivering effective lectures," "facilitating engaging class discussions," and "designing rigorous and relevant college courses." At the end of the fall semester the researcher asked the non-tenure track faculty who had attended the FLC to select three topics they wanted to study during the spring semester. They chose "designing effective assessments," "developing creative lessons to engage students in learning," and "implementing cooperative learning at the college level."

\subsubsection{Administration/Recruitment}

While establishing the FLC, the researcher made several administrative decisions. In an attempt to ensure a successful launch, he facilitated two meetings during the fall semester; then he asked a trusted non-tenure track professor to facilitate the third. Before the spring semester began, he called for volunteers to facilitate the next three meetings, and five faculty members stepped forward to facilitate in pairs or by themselves. In addition to making decisions about the facilitators, the researcher selected the methods for advertising the FLC. He asked department chairs to encourage their non-tenure track faculty to attend, posted information on the university's website, and e-mailed professors directly. The third administrative decision pertained to who could participate, and the researcher decided to make the enrollment open and voluntary so that any non-tenure track faculty at the university could join the group.

\subsubsection{Connections}

During the first meeting the researcher guided the professors in establishing the ground rules for interacting with one another. The purpose of the rules was to establish a collegial environment based on safety, trust, openness, respect, and enjoyment. To build and strengthen the professional connections among colleagues, time was allocated during each meeting for socializing and sharing celebrations and challenges occurring in their home departments. To promote a more welcoming environment, refreshments were served at every meeting.

\subsubsection{Meetings and Activities}

All meetings followed the same basic agenda. As the faculty arrived, they signed in, put on their name badges, picked up any handouts needed for the meeting, enjoyed the refreshments, and visited with other attendees for approximately 10 minutes. Then, the facilitator started the two-hour workshop by conducting an ice-breaker activity that helped the attendees become better acquainted with one another. Next, the facilitator reviewed the workshop objectives and conducted a pre-assessment to determine the professors' background knowledge about the topic. Then, the facilitator gave a short formal presentation on the topic. The presentations were interactive and multi-sensory and were based on adult learning theory. After the formal presentation the professors participated in activities that gave them opportunities to apply the information and share with colleagues. All meetings were held at the university; there were no conferences or retreats at other locations.

\subsubsection{Scholarly Process}

The FLC facilitators used published research as the basis for their presentations, and they e-mailed research articles before and after the meetings. During each meeting the professors reflected on ways that they could apply the information to their teaching. Since participation was voluntary, it was decided to keep the demands placed on the professors at a minimum. Therefore, no formal project was required to document their engagement in the scholarship of teaching and learning.

\subsubsection{Assessment}

The researcher assessed the professors' learning and the FLC itself in a variety of ways. At the conclusion of each meeting the professors offered informal oral feedback on ways to improve the FLC, and they also completed an anonymous written survey to determine what worked and what did not work. At the end of each semester they responded to an e-mail survey inquiring about future topics, facilitators, meeting times, and improvements to the FLC.

\subsubsection{Enablers and Rewards}

The professors with perfect attendance received a certificate of completion and a congratulatory e-mail from the university's provost. No monetary stipends were awarded since there were no available funds in the university's budget. 


\subsection{Participants}

After receiving approval from his university's institutional review board, the researcher hired a research assistant to collect data from the professors participating in the study. He used the research assistant rather than collect the data himself so that the participants would feel more comfortable sharing their opinions about the FLC experience. Also, since the researcher was going to take an active role in developing and managing the FLC, he wanted to minimize any perceived power issue between himself as a university administrator and the study participants.

There were 16 professors in the FLC, and 5 of them agreed to participate in the study. All professors gave their data directly to the research assistant so that neither the researcher nor the other professors in the FLC knew which members of the group were participating in the study. The identities of the five participants were never revealed to the researcher during or after the study. Table 1 provides an overview of the participants. All names are pseudonyms.

Table 1. Overview of the participants

\begin{tabular}{llllll}
\hline Name & Gender & Terminal Degree & Title & $\begin{array}{l}\text { Years Teaching } \\
\text { at the University }\end{array}$ & $\begin{array}{l}\text { Years Teaching } \\
\text { Prior to this Year }\end{array}$ \\
\hline Ann & Female & Doctorate & Clinical Lecturer & 3 & 3 as Clinical Lecturer \\
Sally & Female & Master's & Lecturer & 0 & 3 as Teaching Assistant \\
Lisa & Female & Master's & Adjunct & 0 & 1 as Teaching Assistant \\
Joe & Male & Doctorate & Adjunct & 0 & 2.5 as Teaching Assistant \\
Michael & Male & Doctorate & Adjunct & 0 & 11 in Adult Education \\
\hline
\end{tabular}

\subsection{Data Collection and Analysis}

The data came from three sources: oral interviews, written evaluations, and physical artifacts. First, the research assistant conducted three semi-structured telephone interviews with each participant during the study. The interviews were an opportunity to probe the participants' learning, perceptions of the FLC, and reasons for joining the group. The interviews were also ways to determine the strengths and weaknesses of the FLC professional development approach. After the last FLC meeting the research assistant gave the researcher the audio recordings of the interviews so that he could transcribe them verbatim.

Second, the participants completed anonymous written evaluations after each meeting. All professors who attended the FLC meetings, not just the study participants, completed the evaluations. The study participants wrote a code word at the top of their evaluations so that their comments could be tracked during the study and paired with their interviews. The questions on the evaluations asked participants to identify concepts learned during the meeting, ways that the experience could be improved, and questions that they wanted answered during the next meeting.

Third, the facilitators' curricular materials and handouts were used in the analysis. These physical artifacts allowed the researcher to compare the participants' spoken and written comments with the information intended to be taught.

The researcher employed a within-case analysis and a cross-case comparison of the data from each participant (Miles, Huberman, \& Saldana, 2014). The steps included (a) reading the transcribed interviews and FLC evaluations and writing marginal notes on them, (b) identifying emerging patterns and labeling concepts in the transcribed interviews and FLC evaluations and comparing the patterns and concepts to the physical artifacts, (c) organizing labeled concepts into matrices, and (d) identifying themes. The constant comparative method was used to identify emerging themes from the transcripts, evaluations, and FLC curricular documents (Corbin \& Strauss, 2008). To ensure trustworthiness, the researcher conducted member checks with each participant at the conclusion of the FLC by giving the research assistant his interpretations of the data to pass along to each of the participants. In addition, the researcher triangulated the themes across data sources and kept a journal to record his initial thoughts about the research methodology.

\section{Results}

Two major themes emerged from the analysis of the data. The cohort-based FLC addressed the participants' intellectual and emotional needs. For each of these two major themes, several minor themes also emerged and provided more in-depth analysis. 


\subsection{The FLC and Non-Tenure Track Faculty Members' Intellectual Needs}

The FLC played an important role in helping the participants to learn new pedagogical information. They gained this new knowledge from colleagues, the presenters, and self-reflection. To elaborate, the participants gained pedagogical information from colleagues in the FLC by talking to other non-tenure track professors during the small-group and brainstorming activities. Sally stated, "I learned a lot by talking to my colleagues at the table. I learned some of the methods that they use in class to enhance lecturing such as using visuals and asking questions." Ann wrote in the evaluations, "Our conversations are rich, and the materials that we're given are helpful." When the participants discussed specific strategies with colleagues, they discovered the numerous ways that the strategies were implemented in lessons. Lisa explained in her written evaluations, "The best parts of the FLC were the interactions and the time for sharing ideas. It was nice to hear other people's techniques and other people's ideas of how to work better in the classroom. I really enjoyed that aspect of the learning community a lot.”

In addition to colleagues in the FLC, the participants gained pedagogical information from the presenters. For Joe, the FLC meeting on effective lecturing was especially meaningful. He recounted:

The presenter taught me that you can break up the lecture into different parts so that it's constantly changing and so that it piques people's interest depending on what's going on in the classroom. I learned that there are many ways to keep students involved.

For Sally, the meeting that explored ways to facilitate engaging discussions was informative. She noted in the interviews, "I learned from the presenter how to use specific writing activities to support class discussions. Now I know how to ask my students to record their thoughts in writing before and after the class discussion." In other words, she learned from the presenter how to integrate the literacy skills of reading and writing into her subject area.

Finally, the participants learned pedagogical information by reflecting on what they already knew before the FLC meetings. As the presenters shared information, the participants considered their own instructional approaches and the effectiveness of their efforts. Joe commented in the written evaluations, "The FLC workshop made me more self-aware of what I do as a lecturer." The FLC acted as a mirror that caused the participants to examine themselves carefully. In the written evaluations, Ann wrote, "I feel really validated in terms of my teaching abilities, and now I can transfer these strategies to the courses that I am teaching." She realized the effectiveness of her own teaching and felt ready to add to her existing pedagogical knowledge.

\subsection{The FLC and Non-Tenure Track Faculty Members' Emotional Needs}

Another theme flowed from the data - the FLC addressed the participants' emotional needs. It did so by evoking three emotional responses. First, the participants felt more connected to their colleagues. Over the course of the academic year, the participants began to view themselves as a community because time was allocated for them to socialize and network during each meeting. When asked to identify the best part of the experience, Joe wrote in a feedback form, "It's great to feel like a part of a community!" He had been feeling detached and had wanted to get to know other professors on campus. Sally reiterated this point when asked to explain her reason for joining the FLC. She said during the interview, "I am always looking for opportunities to connect with other professors at our university. I like the interactive nature of the workshop and the opportunity to meet colleagues." The interactions in the FLC positively affected the participants on an emotional level. Lisa wrote, "It was really reassuring to be in a room with a group of people who kinda have similar placements. You know, I'm here on a one-year appointment." Ann summarized the group's general feeling when she wrote in the evaluations, "I'm glad that we're from different disciplines. I feel like I'm part of something instead of feeling isolated."

Second, the participants felt more supported and consequently felt grateful to the university. Michael expressed his feelings of appreciation by stating in his written evaluations, "I'm very glad that this opportunity is available to non-tenure track faculty." Others acknowledged the importance of this support in their careers. Lisa commented, "I'm very fortunate to have the opportunity to take a class like this so early in my time here." She viewed it as a chance to gain some useful pedagogical information to help her to succeed in her teaching. In the final FLC evaluation, Ann wrote:

I appreciated the FLC. I enjoyed it! It was very helpful, especially with me being new to the university. It made me feel much more supported and no longer out there on my own as I would have been otherwise. I feel that it's definitely a worthwhile endeavor.

Third, the participants felt more confident in their teaching abilities. Filled with positive energy, Ann said: 
The faculty learning community gave me a lot of confidence of what I'm doing. It took away my sense of being alone as a teacher in the classroom without a lot of feedback. At time, you don't know if what you're doing is really good or not. You get student feedback but sometimes that just doesn't feel very reliable. So, it made me feel a lot more comfortable about the way that I was running my classroom. To me, that was the main benefit of the experience.

\section{Discussion}

The findings from this study indicate that the cohort-based FLC was a positive professional development experience on both intellectual and emotional levels for the non-tenure track faculty. Through participating in the FLC, they acquired new ideas and instructional strategies and cultivated stronger professional relationships with others who shared the same job assignment. They felt more connected, more supported, and more confident in their abilities to teach at the university.

\subsection{Affirming Previous Research}

The study affirmed findings from previous research on at least four points. First, an FLC by definition is a form of professional development, so it is expected that the individuals who participate in a FLC, like the non-tenure track faculty in this study, would learn new pedagogical information. Other studies have already made this claim (Daly, 2011; Furco \& Moely, 2012; Hershberger et al., 2009; Richlin \& Essington, 2004; Wicks, Craft, Mason, Gritter, \& Bolding, 2015). As Daly clarified, "These faculty learning communities provided a confidential environment for faculty to discuss their challenges, and participants were also able to identify and share information about teaching practices in which they had developed significant expertise" (pp. 11-12). Participating in an FLC with colleagues broadened the faculty members' views beyond their courses and helped them to consider the new pedagogical information on an institutional level. They were able to discuss pedagogical issues regularly with supportive colleagues and receive feedback during the learning process (Furco \& Moely, 2012).

Second, a primary way that professors gain new knowledge in a FLC is by interacting with others. The non-tenure track faculty in this study enjoyed conversing with their colleagues and learning how they taught their students and addressed faculty-related problems in their departments. Explaining why professors participate in this form of professional development, Cox (2003) stated, "Faculty often join an FLC because there is not opportunity for dialogue in their departments. These FLC applicants are hungry for a community in which to engage in this dialogue" (p. 168). Hershberger et al. (2009) also noted the benefits of talking to professors in other subject areas when they wrote, "We learned the true meaning and benefits of interdisciplinary collaborations, with most of the best answers to our myriad questions coming from faculty not in our area" (p. 150). The FLC provides opportunities for faculty members to reflect on their teaching, share creative ideas, and overcome pedagogical challenges (Cervato et al., 2015; Slapcoff \& Harris, 2014). When professors interact with others in a FLC and deepen their professional relationships, they feel more connected to their university (Moore \& Carter-Hicks, 2014).

Third, the study was consistent with previous research regarding professors' increased confidence in their teaching abilities (O'Meara, 2007; Richlin \& Essington, 2004). These researchers in separate studies found that faculty who were studying together in an FLC felt more confident in their teaching, more knowledgeable of students' learning styles, and more willing to experiment with new teaching approaches in the classroom. In short, participation in an FLC revitalized the professors' teaching and courses (Anderson et al., 2014).

Finally, other studies have highlighted the joy that faculty experience in this type of professional development. The non-tenure track faculty in this study delighted in spending two hours together each month and forming professional friendships that enriched their work at the university. Hershberger et al. (2009) noted that the FLC at their university was an "encouraging and supportive mentoring environment" (p. 151). Professors wanted camaraderie with their peers.

\subsection{Adding to Previous Research}

This investigation added to the current research on cohort-based FLCs in several ways. Since a limited number of scholars have examined FLCs for non-tenure track faculty (Brydges et al, 2012; Lambert \& Cox, 2007), this study's findings add to the field. Specifically, the findings regarding the non-tenure track professors' gaining pedagogical information sheds light on an important point that may be overlooked in the literature. The professors in this FLC had little or no formal teaching experience before the school year began. FLCs for non-tenure track faculty constitute one way that universities can support new faculty and give them the tools and support to thrive and succeed at their institutions. At the conclusion of their study on professional development for adjuncts, Johnson and Stevens (2008) recommended, "With the large number of adjunct faculty members employed in higher education, colleges have the 
challenge of supporting these individuals who have little connection to the institution other than the classes they teach. The isolation and marginalization felt by adjunct faculty in higher education is in need of mending" (p. 28).

Furthermore, the non-tenure track professors' comments, coupled with those made by other professorial groups, suggest that all have fears related to their work at the university. Previous studies have discussed each group's concerns. Tenure-track professors worry about achieving tenure at their universities, and senior faculty worry about "mattering" or remaining relevant (Blaisdell \& Cox, 2004). The data from this study suggest that some non-tenure track faculty feel isolation (Durso, 2011) and a lack of commitment from their institutions (Dolan et al., 2013). The FLC becomes critical because, by the very nature of their position, they may not have full-time teaching positions, service opportunities, or opportunities to interact with others. In short, the FLC addresses these issues and acts as an integral support system with colleagues in the same rank.

Another important finding from the study is that universities need to offer professional development specifically tailored to non-tenure track faculty. Although they are encouraged to attend the general professional development workshops for faculty, they often feel that these opportunities do not address their unique needs. They want to exchange information and ideas with others who are experiencing the same issues, such as isolation and feeling uninformed about the workings of their department. Universities need to develop programs that integrate more deeply the non-tenure track faculty into the culture of the school. In Lambert and Cox's (2007) study, adjuncts stated that they did not participate in the FLC because they thought it was not designed for them. Viskovic (2006) writes, "Institutions have a responsibility to foster an overall climate or culture that values teaching and learning, recognizes and rewards teacher excellence, and supports continuing professional development" (p. 334). Similarly, Dee and Daly (2009) state that "faculty development programs can play an important role on college and university campuses by acknowledging the human needs of faculty members, and by providing the resources, social networks, and innovative ideas that can foster the fulfillment of those needs" (p. 2). FLCs are one way these aims can be achieved.

\subsection{Limitations and Areas for Further Research}

The study included several limitations that could be addressed in future research. First, the research assistant lacked in-depth knowledge of FLCs, even though she had been a K-16 teacher for many years. The researcher employed her to collect the data in order to minimize any perceived power issues between the participants and the researcher, who was a part-time administrator. It might have been better for the researcher to collect the data since he would have been able to probe more deeply during the interviews.

Second, the study did not include all of the FLC components that Cox (2004) recommends. Future researchers may want to replicate the study and expand on this research. Because this was the first time that the university implemented the FLC, the researcher decided to keep the format straightforward and uncomplicated. Future researchers might examine what happens if non-tenure track faculty are selected through an application process to participate, receive a stipend, and complete a project that focuses on teaching and learning.

Third, the research instruments collected only data that pertained to the participants' experiences during the FLC. In short, the participants self-reported what they learned and how they improved as teachers. Including a more objective measure, such as a scholarly product or the participants' students' comments, would have enhanced the findings. Cox (2004) recommends that FLC participants create a scholarly product to assess their learning. This component was omitted because the researcher did not want to burden the already-busy non-tenure track faculty. Sleeter (2014) claims, "Various kinds of impact can be studied. Impact on teachers, for example, might be pedagogical (how teachers teach), but one can also study teacher knowledge, teacher attitudes, teacher identity, and so forth" (p. 148). Further research could single out one of these areas of impact for a deeper examination.

Finally, a cursory analysis of the data did not show any differences among the participants at the different ranks of adjuncts, lecturer, and clinical lecturer. Scholars might conduct future research on the different types of non-tenure track since they are not a homogenous group (Cross \& Goldenberg, 2009). Each may approach the experience of being in an FLC differently.

\section{Conclusion}

Offering FLCs specifically for non-tenure track faculty is beneficial to the participants and to the institution. Like FLCs for tenure-eligible faculty, FLCs for non-tenure track faculty foster colleagueship and learning from others; help to develop teaching skills, ability, and confidence; and increase participants' connection to the institution. Just as educators differentiate their instruction for different types of students in their classes, it is wise for universities to differentiate their professional development for various types of professors. 


\section{Acknowledgements}

The author thanks Kathleen Magor for her assistance copyediting this manuscript.

\section{References}

Alejano-Steele, A., Hamington, M., MacDonald, L., Potter, M., Schafer, S., Sgoutas, A., \& Tull, T. (2011). From difficult dialogues to critical conversations: Intersectionality in our teaching and professional lives. New Directions for Teaching and Learning, 125, 91-100. http://dx.doi.org/10.1002/t1.436

American Association of University Professors. (2011). Trends in instructional staff employment status, 1975-2011. Retrieved from http://www.aaup.org/sites/default/files/files/AAUP_Report_InstrStaff-75-11_apr2013.pdf

Anderson, J. R., Bond, B., Davis-Street, J., Gentlewarrior, S., Savas, M., \& Sheeny, D. (2014). Transforming the classroom - and the world: Voices from a culturally inclusive pedagogy faculty learning community. Transformative Dialogues: Teaching and Learning Journal, 7(1), 1-18.

Barnshaw, J., \& Dunietz, S. (2015). Busting the myths: The annual report on the economic status of the profession, 2014-2015. Academe, 101(2), 4-19.

Baron-Nixon, L. (2007). Connecting non-full-time faculty to institutional mission. Sterling, VA: Stylus.

Barton, B., Oates, G., Paterson, J., \& Thomas, M. (2015). A marriage of continuance: Professional development for mathematics lecturers. Mathematics Education Research Journal, 27(2), 147-164. http://dx.doi.org/10.1007/s13394-014-0134-7

Blaisdell, M. L., \& Cox, M. D. (2004). Midcareer and senior faculty learning communities: Learning throughout faculty careers. In M. D. Cox \& L. Richlin (Eds.), Building faculty learning communities (pp. 137 - 148). New Directions for Teaching and Learning, No. 97. San Francisco, CA: Jossey-Bass.

Breen, S., McCluskey, A., Meehan, M., O'Donovan, J., \& O'Shea, A. (2014). A year of engaging with the discipline of noticing: Five mathematics lecturers' reflections. Teaching in Higher Education, 19(3), 289-300. http://dx.doi.org/10.1080/13562517.2013.860107

Brydges, S., Chilukuri, L., Cook, G., Feeley, M., Herbst, M., Tour, E., \& Van Den Eide, L. (2012). Building a faculty leaning community at a research university. Currents in Teaching and Learning, 5(1\&2), 17-35.

Cervato, C., Gallus, W., Slade, M., Kawaler, S., Marengo, M., Woo, K., \& Acerbo, M, et.al. (2015). It takes a village to make a scientist: Reflections of a faculty learning community. Journal of College Science Teaching, 44(3), 22-29. http://dx.doi.org/10.2505/4/jcst15_044_03_22

Cilliers, F. J., \& Herman, N. (2010). Impact of an educational development programme on teaching practice of academics at a research-intensive university. International Journal for Academic Development, 15(3), 253-267. http://dx.doi.org/10.1080/1360144X.2010.497698

Corbin, J., \& Strauss, A. (2008). Basics of qualitative research: Techniques and procedures for developing grounded theory. Thousand Oaks, CA: Sage Publications.

Cox, M. D. (2003). Fostering the scholarship of teaching and learning through faculty learning communities. Journal on Excellence in College Teaching, 14(2/3), 161-198.

Cox, M. D. (2004). Introduction to faculty learning communities. In M. D. Cox \& L. Richlin (Eds.), Building faculty learning communities (pp. 5 - 23). New Directions for Teaching and Learning, No. 97. San Francisco, CA: Jossey-Bass. http://dx.doi.org/10.1002/tl.129

Cox, M. D. (2009). FLC program director's and facilitator's handbook. Miami: OH: Author.

Cox, M. D. (2013). The impact of communities of practice in support of early-career academics. International Journal for Academic Development, 18(1), 18-30. http://dx.doi.org/10.1080/1360144X.2011.599600

Cross, J. G., \& Goldenberg, E. N. (2009). Off-track profs: Nontenured teachers in higher education. Cambridge, MA: MIT Press.

Cressman, J. R. (2011). Professional development of the adjunct faculty. In L. Cooper \& B. Booth (Eds.), The adjunct faculty handbook (pp. 63-72). Los Angeles, CA: Sage. http://dx.doi.org/10.4135/9781452204741.n5

Daly, C. J. (2011). Faculty learning communities: Addressing the professional needs of faculty and the learning needs of students. Currents in Teaching and Learning, 4(1), 3-16. 
Dee, J., \& Daly, C. (2009). Innovative models for organizing faculty development programs: Pedagogical reflexivity, student learning empathy, and faculty agency. Human Architecture: Journal of the Sociology of Self-Knowledge, 7(1), 1-22.

Dolan, D. M., Hall, M. S., Karlsson, C. R., \& Martinak, M. L. (2013). Five years later: Maryland adjuncts tell us (again) who they are and what they want. The Journal of Continuing Higher Education, 61(1), 35-45. http://dx.doi.org/10.1080/07377363.2013.758552

Durso, M. C. (2011). Reflections from an adjunct: How the scholarship of teaching and learning empowers the part-time instructor. InSight: A Journal of Scholarly Teaching, 6, 37-42.

Ebersole, T. E. (2008). The impact of a new faculty learning community on perceived and actual student learning outcomes. Journal of Faculty Development, 22(1), 71-80.

Fullan, M. (2007). The new meaning of educational change. New York, NY: Teachers College Press.

Furco, A., \& Moely, B. E. (2012). Using learning communities to build faculty support for pedagogical innovation: A multi-campus study. The Journal of Higher Education, 83(1), 128-153. http://dx.doi.org/10.1353/jhe.2012.0006

Gadberry, J. L., \& Burnstad, H. (2005). One faculty: Hiring practices and orientation. In D. L. Wallin (Ed.), Adjunct faculty in community colleges: An academic administrator's guide to recruiting, supporting, and retaining great teachers (pp. 75-96). Bolton, MA: Anker.

Gappa, J. M., \& Leslie, D. W. (1993). The invisible faculty: Improving the status of part-time faculty in higher education. San Francisco, CA: Jossey-Bass.

Garri, B., \& Petersen, N. J. (2006). Noncore faculty members' roles: Expectations and system stress. The Educational Forum, 70(3), 215-221. http://dx.doi.org/10.1080/00131720608984898

Gillespie, K. J., Robertson, D. L., \& Associates (2010). A guide to faculty development. San Francisco, CA: Jossey-Bass.

Hadar, L., \& Brody, D. (2010). From isolation to symphonic harmony: Building a professional development community among teacher educators. Teaching and Teacher Education, 26(8), 1641-1651. http://dx.doi.org/10.1016/j.tate.2010.06.015

Hershberger, A., Spence, M., Cesarini, P., Mara, A., Jorissen, K. T., Albrecht, D., Gordon, J. J., \& Lin, C. (2009). The ripple effect: Lessons from a research and teaching faculty learning community. Journal on Excellence in College Teaching, 20(3), 145-173.

Hoeller, K. (Ed.) (2014). Equality for contingent faculty: Overcoming the two-tiered system. Nashville, TN: Vanderbilt University Press.

Hoyt, J. E. (2012). Predicting the satisfaction and loyalty of adjunct faculty. The Journal of Continuing Higher Education, 60, 132-142. http://dx.doi.org/10.1080/07377363.2013.722417

Hubball, H., \& Albon, S. (2007). Faculty learning communities: Enhancing the scholarship of teaching, learning, and curriculum practice. Journal on Excellence in College Teaching, 18(2), 119-141.

Johnson, C., \& Stevens, C. (2008). Creating links: An inclusive faculty development initiative. Adult Learning, 19(1-2), 26-29.

Kezar, A. (Ed.). (2012). Embracing non-tenure track faculty: Changing campuses for the new faculty majority. New York, NY: Routledge.

Kezar, A., \& Sam, C. (2011). Understanding non-tenure track faculty: New assumptions and theories for conceptualizing behavior. American Behavior Scientist, 55(11), 1419-1442. http://dx.doi.org/10.1177/000276211408879

Lambert, H. E., \& Cox, M. D. (2007). The two-year effort to build a program that provides part-time faculty pedagogical support, community, and a sense of mission. In R. E. Lyons (Ed.), Best practices for supporting adjunct faculty (pp. 217-231). Bolton, MA: Anker.

Lyons, R. E. (2007). Deeping our understanding of adjunct faculty. In R. E. Lyons (Ed.), Best practices for supporting adjunct faculty (pp. 1-12). Bolton, MA: Anker.

Maisto, M., \& Street, S. (2011). Confronting contingency: Faculty equity and the goals of academic democracy. Liberal Education, 97(1), 6-13. 
Mallory, B. P., Fisher, D. J., Witham, A. R., \& Gultice, A. D. (2014). With a little help from my friends: How faculty peer review can transform mediocre teaching methods into powerful learning experiences. AURCO Journal, 20, 192-203.

Miles, M. B., Huberman, A. M., \& Saldana, J. (2014). Qualitative data analysis. An methods sourcebook (3rd ed.). Thousand Oaks, CA: Sage Publications.

Moore, J. A., \& Carter-Hicks, J. (2014). Let's talk! Facilitating a faculty learning community using a critical friends group approach. International Journal for the Scholarship of Teaching and Learning, 8(2), 1-17.

O'Meara, K. (2007). Stepping up: How one faculty learning community influenced faculty members' understanding and use of active learning methods and course design. Journal on Excellence in College Teaching, 18(2), $97-118$.

Parrott, T. M., Grabinski, C. J., Silverstein, N. M., Spencer, M., Takayanagi, P. W., \& Yee-Melichar, D. (2007). Part-time faculty and gerontology programs: Dilemmas and solutions. Gerontology and Geriatrics Education, 27(4), 69-83. http://dx.doi.org/10.1300/J021v27n04_05

Richlin, L., \& Essington, A. (2004). Faculty learning communities for preparing future faculty. In M. D. Cox \& L. Richlin (Eds.), Building faculty learning communities (pp. 149 - 157). New Directions for Teaching and Learning, No. 97. San Francisco, CA: Jossey-Bass. http://dx.doi.org/10.1002/tl.141

Schreyer, J. (2012). Inviting the "outsiders" in: Local efforts to improve adjunct working conditions. Journal of Basic Writing, 31(2), 83-102.

Schuster, J. H., \& Finkelstein, M. J. (2006). American faculty: The restructuring of academic work and careers. Baltimore, MD: Johns Hopkins University Press.

Senge, P. M. (1990). The fifth discipline. New York, NY: Doubleday.

Slapcoff, M., \& Harris, D. (2014). The Inquiry Network: A model for promoting the teaching-research nexus in higher education. Canadian Journal of Higher Education, 44(2), 68-84.

Sleeter, C. (2014). Toward teacher education research that informs policy. Educational Researcher, 43(3), 146-153. http://dx.doi.org/10.3102/0013189X14528752

Smith, T. R., McGowan, J., Allen, A. R., Johnson, W. D., II, Dickson, L. A., Jr., Najee-ullah, M. A., \& Peters, M. (2008). Evaluating the impact of a faculty learning community on STEM teaching and learning. The Journal of Negro Education, 77(3), 203-226.

Stes, A., Min-Leliveld, M., Gijbels, D., \& Van Petegem, P. (2010). The impact of instructional development in higher education: The state-of-the-art of the research. Educational Research Review, 5(1), 25-49. http://dx.doi.org/10.1016/j.edurev.2009.07.001

Thedwall, K. (2008). Non-tenure-track faculty: Rising numbers, lost opportunities. New Directions for Higher Education, 143, 11-19. http://dx.doi.org/10.1002/he.308

U.S. Department of Education. (2009). National Center for Education Statistics. Digest of Education Statistics. Retrieved from http://nces.ed.gov/programs/digest/d09/tables/dt09_249.asp

Viskovic, A. (2006). Becoming a tertiary teacher: Learning in communities of practice. Higher Education Research and Development, 25(4), 323-339. http://dx.doi.org/10.1080/07294360600947285

Webster-Wright, A. (2009). Reframing professional development through understanding authentic professional learning. Review of Educational Research, 79(2), 702-739. http://dx.doi.org/10.3102/0034654308330970

Wicks, D. A., Craft, B. B., Mason, G. N., Gritter, K., \& Bolding, K. (2015). An investigation into the community of inquiry of blended classrooms by a faculty learning community. Internet and Higher Education, 25(53-62). http://dx.doi.org/10.1016/j.iheduc.2014.12.001

Wong, O. (2013). An instructor primer for adjunct and new faculty: Foundations for career success. Lanham, MD: Rowman \& Littlefield Publishers. 